\title{
Studies of Flow
}

\section{In Alluvial Channels}

GEOLOGICAL SURVEY WATER-SUPPLY PAPER 1498

This volume was published

as separate chapters $A-I$

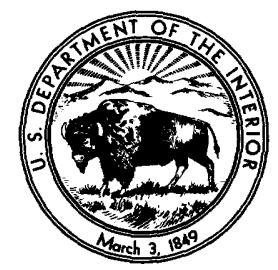


UNITED STATES DEPARTMENT OF THE INTERIOR STEWART L. UDALL, Secretary

\author{
GEOLOGIGAL SURVEY \\ William T. Pecora, Director
}

Library of Congress catalog-card No. GS 65-403 


\section{CONTENTS}

[Letters designate the separately published chapters]

(A) Flume studies using medium sand $(0.45 \mathrm{~mm})$, by D. B. Simons, E. V. Richardson, and M. L. Albertson.

(B) Flow characteristics of Elkhorn River, near Waterloo, Nebraska, by E. W. Beckman and L. W. Furness.

(C) Depth-discharge relations of alluvial streams-discontinuous rating curves, by David R. Dawdy.

(D) Effect of depth of flow on discharge of bed material, by Bruce R. Colby.

(E) The effect of bed roughness on depth-discharge relations in alluvial channels, by D. B. Simons and E. V. Richardson.

(F) A study of fluvial characteristics and hydraulic variables, middle Rio Grande, New Mexico, by James K. Culbertson and David R. Dawdy.

(G) Some effects of fine sediment on flow phenomena, by D. B. Simons, E. V. Richardson, and W. L. Haushild.

(H) Aspects of flow resistance and sediment transport, Rio Grande near Bernalillo, New Mexico, by Carl F. Nordin, Jr.

(I) Total bed-material discharge in alluvial channels, by F. M. Chang, D. B. Simons, and E. V. Richardson. 